\title{
How do pre-service physics teachers see sustainability issues? A case at an Islamic University in Indonesia
}

\author{
Dindin Nasrudin $^{1}$, Agus Setiawan ${ }^{2}$, and Dadi Rusdiana ${ }^{3}$ \\ \{dindin.nasrudin@upi.edu¹, agus_setiawan@upi.edu² ${ }^{2}$ and dadirusdiana@upi.edu ${ }^{3}$ \} \\ Program Studi S3 Pendidikan IPA, Sekolah Pascasarjana, Universitas Pendidikan Indonesia Jl. Dr. \\ Setiabudhi No.229, Bandung, Indonesia ${ }^{1}$, Departemen Pendidikan Teknik Mesin, Universitas Pendidikan \\ Indonesia, Jl. Dr. Setiabudhi No.229, Bandung, Indonesia ${ }^{2}$, Departemen Pendidikan Fisika, Universitas \\ Pendidikan Indonesia, J1. Dr. Setiabudi No. 229, Bandung, Indonesia ${ }^{3}$
}

\begin{abstract}
The issue of Education for Sustainable Development (ESD) has long been launched. However, this concept has not been understood by everyone including preservice physics teachers. This paper aims to describe the profile of understanding physics teacher candidates on sustainability issues in the context of education. The method used is qualitative through in-depth interviews with several respondents. The results of the study show that the understanding of pre-service physics teachers about sustainability issues is still low. A program that is planned, systematic and measurable is needed to improve their literacy-related to sustainability issues that are integrated into the lecture material.
\end{abstract}

Keywords: ESD, Renewable Energy Education, SDG's, Sustainability Literacy

\section{Introduction}

The initiative to include sustainable development as an educational goal was rolled out by the Talloires Declaration in 1990 and strengthened by the 2009 UNESCO World Conference on Education for Sustainable Development (ESD) [1]. Educational institutions have an important role in promoting sustainable development models as a center of knowledge and innovation as well as institutions that are expected to become sustainable organizations [2,3]. Providers of higher education can contribute to the achievement of sustainable development goals by producing graduates with knowledge, skills, attitudes, and attributes that are sustainable [4]. However, the facts show that many higher education institutions in the world have not fully developed a plan to consider matters relating to sustainable development [5], even though higher education represents significant resources to make it happen [6].

In the Indonesian context, the role of tertiary institutions related to ESD is highly expected in the success of the Sustainable Development Goals (SDG's) program which will be implemented until 2030, one of which is related to environmental issues and energy availability. Higher education is expected to support the success of the government in solving environmental and energy problems through education, teaching and learning, human resource development, curriculum review and research [7,8]. The transformation of learning, as well as the transformative approach on matters related to sustainable development, must also be integrated into the curriculum and learning [9].

ESD implementation strategies at the tertiary level can come from leaders (Top-Down), or come from lower management proposals at the study program level (Bottom-Up) or even a 
mixed approach to both [10]. One effort to implement ESD at the study program level is to open elective courses. For example renewable energy courses. In Islamic tertiary institutions, the discussion on ESD is very relevant to religious studies originating from the holy verses. Integrating renewable energy education with a religious approach is possible to be an alternative to civilizing ESD in tertiary institutions. This paper aims to describe the literacy profile of prospective physics teachers who will take renewable energy courses related to sustainability issues in the context of education for sustainable development and its relation to the message of the scriptures.

\section{Method}

This research is preliminary research conducted at the beginning of the elective Renewable Energy (RE) opening course. The method used is a qualitative method through open-ended questions followed by in-depth interviews. A number of questions were given to 28 candidates for physics teachers. Each prospective physics teacher who will choose a group of elective courses in the first year of level III is asked the following questions:

1. Have you ever heard the term Sustainable Development Goal (SDG's)? If yes, explain!

2. Have you ever heard of the term Education for Sustainable Development (ESD)? If yes, explain!

3. What do you know about Renewable Energy (RE)?

Respondents' answers are categorized into four levels namely $0=$ no understanding; $1=$ basic understanding; 2 = strong understanding; and 3 = deep understanding. Respondents' answers were analyzed and mapped into profiles of the teacher's initial understanding of the issue of "sustainability".

To reinforce written answers, several respondents were asked for information through indepth interviews while being asked about their attitudes and interests in attending renewable energy lectures. Exploring respondents' knowledge of religious guidance related to the ESD issue will be used as additional data in this study because the respondents are students at religious colleges. Today, religion is no longer a neglected dimension in development studies. The literature on religion and development has not only developed over the past decade, but partnerships between international development institutions and religious communities have also multiplied [11].

\section{Result and Discussion}

SDG's is a blueprint for achieving a better and more sustainable future for everyone. Griggs et.al (2013) divide into 17 global issues into 6 main objectives. Two of them are (1): Universal clean energy, by increasing universal and affordable access to clean energy that minimizes local pollution and health impacts and mitigates global warming and (2) Governance for sustainable communities, by changing governance and institutions in all tiers, including educational institutions, to tackle five other sustainable development goals [12]. Efforts to succeed the SDG's program were responded by universities through ESD.

Education is an important tool for achieving sustainability [13]. One of the roles of the world of education is to provide learning outcomes that impact change at an early stage [14] and social change at an advanced stage [15]. The relationship between education and sustainable 
development is not simple. At the very least, in general, research shows that basic education is the key to the nation's ability to develop and achieve sustainability targets. In practice, education directly influences sustainability plans in the following three areas: implementation, decision making, and quality of life [16].

Implementation of sustainability programs at the level of renewable energy courses begins with obtaining initial profile data on the level of basic understanding of terms related to sustainability. This data is a baseline for further program development. Figure $\mathbf{1}$ below shows the initial profile of students about the concepts of SDG, ESD, and RE. Their average understanding of the issue of sustainability is 0.25 for the SDG concept, 0.32 for the ESD concept and 0.96 for the RE concept. In general, their knowledge and understanding of sustainability issues is still weak (under number 1) on a scale of $0-4$. There is only 1 student who has an understanding at the level of strong understanding (level 3) on the RE and ESD concepts. Not one student has reached the same level in SDG's concept. This result strengthens previous research [17].

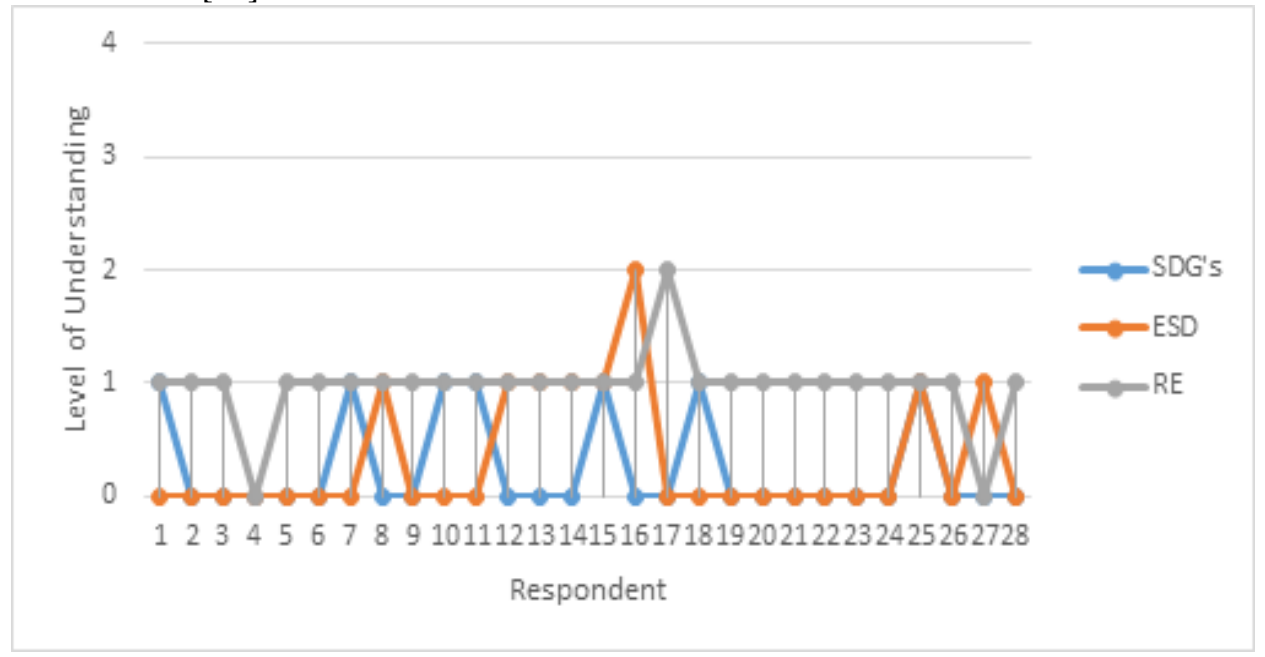

Fig. 1. The level of student understanding baseline sustainability issues.

The low understanding of students on the basic concept of sustainability is a crucial problem that must be addressed immediately. This data shows the low level of public literacy on global issues around them. In fact, the main thing that must be owned by the community is basic knowledge. Without basic knowledge, citizens are not aware of environmental problems and cannot even begin to experience them adequately. The lack of environmental literacy, the value of sustainability, connectedness with nature, and environmental education as core subjects need to be addressed through education reform. The best approach to environmental education requires the transformation of a rooted and standardized education system [18]. Higher education has an important role in building community capacity to realize change especially in the way the community prepares itself to overcome energy and environmental problems [19].

The topic of environment and renewable energy are two things that are closely related to the context of education for sustainable development. Sustainable development is a multidimensional problem. According to Starcic, Terlevic, Lin, \& Lebenicnik (2018), there are three things that drive change in higher education institutions as well as implications for teaching and learning. First, the theme of sustainable development must be contextualized and 
awareness of sustainable development or declarative knowledge must be applied in practice. Second, online social media must support the whole system approach and as an important source of social capital. Third, the teaching and learning of sustainable development literacy must take into account and connect to everyday personal lifestyles [20].

On a practical level, the implementation of ESD in higher education requires an integration and collaboration approach with other institutions [21], in addition to the learning approach within the institution. With the development of the concept of ESD from various concepts, it is also necessary to enrich the concept of elementary school which is more holistic for prospective teachers [22]. Aside from enriching courses, sustainability issues should also be introduced to new students in the early semester. Introducing students to the topic of sustainability at the beginning of studies at the university is an important first step in developing sustainability education in the higher education sector [23]. As a result, teacher candidates generated through education in tertiary institutions applying the concept of sustainability will become teachers who have four ways of thinking at the same time: futures thinking, values thinking, systems thinking, and strategic thinking [24].

For religious tertiary institutions, the concept of ESD is very relevant if it is integrated with the religious guidance contained in the scriptures. Interviews with students obtained information that before they took the renewable energy course, they also had gained religious insight about the importance of preserving nature by not destroying it. A learning integration model that links the concepts of religion and science in studying and succeeding in the ESD program is needed. Previous research shows how religious teachings influence sustainable development practices such as agriculture [25], economics [26] and solid waste management [27]. The rise of interest in religion in the context of international development must be welcomed [28] because understanding the dynamics of religion and the role of communities and religious actors is crucial for sustainable development [29]. Although disjunction implied by "religion and development" has been considered wrong, at least we can still make a meaningful relationship between the two with a new disjunctionin namely: "religion in development," [30].

\section{Conclusion}

Profile of initial understanding of physics teacher candidates regarding sustainability issues is still low. Therefore, it is necessary to increase literacy through lecture programs that discuss ESD specifically both theoretically and practically. For example renewable energy education and environmental education. Increased sustainability literacy will be more effective if given early. It is also possible to collaborate and integrate ESD learning with religious courses in Islamic universities with an appropriate approach.

\section{References}

[1] Wals, A.E. and Kieft, G.: Education for sustainable development. Research overview. Sida (2010)

[2] Yáñez, S., Uruburu, Á., Moreno, A. and Lumbreras, J.: The sustainability report as an essential tool for the holistic and strategic vision of higher education institutions. Journal of cleaner production (2019) [3] Aleixo, A.M., Leal, S., Azeiteiro, U.M.: Conceptualization of sustainable higher education institutions, roles, barriers, and challenges for sustainability: An exploratory study in Portugal. Journal of Cleaner Production (2018) 
[4] Opoku, A. and Egbu, C.: Students' perspectives on the relevance of sustainability literacy in a postgraduate built environment program. International Journal of Construction Education and Research (2018)

[5] Leal, F.W., Skanavis, C., Kounani, A., Brandli, L.L., Shiel, C., do Paço, A., Pace, P., Mifsud. M., Beynaghi, A., Price, E. and Salvia, A.L.: The role of planning in implementing sustainable development in a higher education context. Journal of Cleaner Production (2019)

[6] Shawe, R., Horan, W., Moles, R. and O'Regan, B.: Mapping of sustainability policies and initiatives in higher education institutes. Environmental Science \& Policy (2019)

[7] Vargas, V.R., Lawthom, R., Prowse, A., Randles, S., Tzoulas, K.: Implications of vertical policy integration for sustainable development implementation in higher education institutions. Journal of Cleaner Production (2019)

[8] Milutinović, S. and Nikolić, V.: Rethinking higher education for sustainable development in Serbia: an assessment of Copernicus charter principles in current higher education practices. Journal of cleaner production (2014)

[9] Leal, F.W., Raath, S., Lazzarini, B., Vargas, V.R., de Souza, L., Anholon, R., Quelhas, O.L., Haddad, R., Klavins, M. and Orlovic, V.L.: The role of transformation in learning and education for sustainability. Journal of cleaner production (2018)

[10] Ramísio, P.J., Pinto, L.M., Gouveia, N., Costa, H. and Arezes, D.: Sustainability Strategy in Higher Education Institutions: Lessons learned from a nine-year case study. Journal of Cleaner Production (2019)

[11] Deneulin, S. and Zampini-Davies, A.: Engaging development and religion: Methodological groundings. World Development (2017)

[12] Griggs D, Stafford-Smith M, Gaffney O, Rockström J, Öhman MC, Shyamsundar P, Steffen W, Glaser G, Kanie N, Noble I.: Policy: Sustainable development goals for people and planet. Nature. (2013)

[13] Hopkins, C. and McKeown, R.: Education for sustainable development: an international perspective. Education and sustainability: Responding to the global challenge (2012)

[14] Arbuthnott, K.D.: Education for sustainable development beyond attitude change. International Journal of Sustainability in Higher Education (2009)

[15] Vare, P. and Scott, W.: Learning for a change: Exploring the relationship between education and sustainable development. Journal of Education for Sustainable Development (2007)

[16] McKeown, R., Hopkins, C.A., Rizi, R. and Chrystalbridge, M.: Education for sustainable development toolkit. Knoxville: Energy, Environment and Resources Center, University of Tennessee (2002)

[17] Wojuola, R.N. and Alant, B.P.: Sustainable development and energy education in Nigeria. Renewable energy. Vol. 1 No.139 pp. 1366-1374 (2019)

[18] Singleton, J.: Environmental Literacy And Sustainability Values: A Content Analysis Of Environmental Education Standards. Eco-thinking (2016)

[19] Tilbury, D. and Wortman, D.: Engaging people in sustainability. IUCN (2004)

[20] Starcic, A.I., Terlevic, M., Lin, L. and Lebenicnik, M.: Designing Learning for Sustainable Development: Digital Practices as Boundary Crossers and Predictors of Sustainable Lifestyles. Sustainability (2018)

[21] Anand, C.K., Bisaillon, V., Webster, A. and Amor, B.: Integration of sustainable development in higher education-a regional initiative in Quebec (Canada). Journal of Cleaner Production (2015)

[22] Sinakou, E., de Pauw, B.J., Van, P.P.: Exploring the concept of sustainable development within education for sustainable development: implications for ESD research and practice. Environment, development and sustainability (2019)

[23] Carmichael, C.E. and Handa, N.: Sustainability literacy counts: raising awareness through a preparatory University program. International Journal of Sustainability Education (2014)

[24] Warren, A., Archambault, L., and Foley, R.W.: Sustainability Education Framework for Teachers: Developing sustainability literacy through futures, values, systems, and strategic thinking. Journal of Sustainability Education (2014) 
[25] Shiva, V., Deutscher, Y., Hurtado, L., Pembamoyo, E., Lemons, M., Adhikari, J., Jain, P., Sanford, A.W., Dixon, M.H., Sutterfield, R. and Abouleish-Boes, M.: Religion and Sustainable Agriculture: World Spiritual Traditions and Food Ethics. University Press of Kentucky (2016)

[26] Gutsche, G.: Individual and regional Christian religion and the consideration of sustainable criteria in consumption and investment decisions: An exploratory econometric analysis. Journal of Business Ethics (2019)

[27] Mohamad, Z.F., Idris, N. and Mamat, Z.: Role of religious communities in enhancing transition experiments: a localised strategy for sustainable solid waste management in Malaysia. Sustainability science (2012)

[28] Ager, A., Ager, J.: Sustainable development and religion: Accommodating diversity in a postsecular age. The Review of Faith \& International Affairs (2016)

[29] Tomalin, E., Haustein, J. and Kidy, S.: Religion and the Sustainable Development Goals. The Review of Faith \& International Affairs (2019)

[30] Cochrane, J.R.: Religion in Sustainable Development.: The Review of Faith \& International Affairs (2016) 